\title{
PEMBERDAYAAN EKONOMI KELOMPOK PEREMPUAN MELALUI BUDIDAYA HORTIKULTURA SECARA ORGANIK DALAM POLYBAG DI LAHAN PEKARANGAN DESA TANAK AWU KECAMATAN PUJUT LOMBOK TENGAH
}

\author{
Candra $\mathrm{Ayu}^{*}{ }^{*}$, Lolita Endang Susilawati. I Wayan Sudika, Bambang Budi Santoso, dan \\ Muktasam \\ Fakultas Pertanian Universitas Mataram \\ ${ }^{*}$ Korespondensi: ayucandra22@unram.ac.id
}

Diterima 28 September 2018 / Disetujui 15 November 2018

\begin{abstract}
ABSTRAK
Desa Tanak Awu adalah salah satu desa di Kecamatan Pujut-Kabupaten Lombok Tengah dan merupakan tempat Bandara Internasional Lombok. Sumber mata pencaharian penduduk Desa Tanak Awu adalah sebagai petani lahan kering meskipun produktivitas dan pendapatan dari sistem pertanian ini rendah sehingga mengakibatkan kemiskinan. Kemiskinan dan rendahnya produktivitas pertanian di desa ini mengakibatkan kurangnya kemampuan pengadaan modal untuk aplikasi input pertanian secara optimal dan untuk pengupahan tenaga kerja. Namun, berdasarkan hasil penelitian yang terkait dengan model pemberdaayaan kelompok perempuan yang disuluhkan pada kegiatan ini ditemukan kondisi kontra-produktif tradisi patriarhi yang dianut masyarakat. Kelompok perempuan tidak bekerja di lahan pertaniannya, partisipasinya sebatas penyedia makanan untuk pekerja liar keluarga. Secara kultural peran mencari nafkah terbeban mutlak di kelompok laki-laki dan potensi produktif perempuan terpendam meskipun kekurangan tenaga kerja untuk mengelola usahataninya. Untuk itu, kegiatan pengabdian kepada masyarakat ini bertujuan memberdayakan potensi kerja kelompok perempuan melalui pengembangan kegiatan produktif-ekonomi yang selaras tradisi. Tradisi tersebut memilik potensi positip yakni tersedianya banyak waktu luang kelompok perempuan diantara aktivitas domestikasi dan disuluhkan untuk pengembangan sistem pertanian organik tanaman hortikultura dalam wadah polybag di halaman pekarangan. Sistem binaan ini selaras tradisi serta hemat lahan dan waktu pengelolaan sehingga lebih optimal perolehan produksi dan pendapatannya. Implikasinya adalah kelompok perempuan dapat berkontribusi secara ekonomi untuk membebaskan keluarganya dari kemiskinan.
\end{abstract}

Kata kunci: pemberdayaan, kelompok perempuan, tradisi patriarkhi, pekarangan.

PENDAHULUAN

Desa Tanak Awu adalah salah satu desa di wilayah Kecamatan Pujut, Kabupaten Lombok Tengah. Keistimewaan Desa Tanak Awu adalah menjadi tempat Bandara Internasional Lombok (BIL) dan jarak dengan pemukiman penduduk lokal sekitar kurang dari 1 kilometer. Namun, keberadaan BIL sejak tahun 2011 belum dapat memberi 
manfaat ekonomi secara langsung bagi penduduk lokal akibat kurangnya kualifikasi untuk dapat berperan dalam administrasi pengelolaan BIL maupun akibat kurangnya kemampuan menangkap peluang bisnis di kawasan tersebut.

Hasil penelitian Candra Ayu dkk (2014) mengungkapkan bahwa sumber penghidupan utama bahkan satu-satunya penduduk di Desa Tanak Awu adalah dari bertani di lahan kering. Jenis tanaman yang diusahakan adalah padi dan palawija dengan frekwensi tanam 1 sampai 2 kali per tahun. Meskipun produktivitas usahatani tersebut tergolong sangat rendah, yakni padi hanya 3,63 ton/ha namun belum ada upaya menekuni bidang usaha lain di luar pertanian melalui pemanfaatan kawasan sekitar BIL sebagai tempat usaha baru. Hal ini mengakibatkan rendahnya pendapatan petani dan secara langsung menjadi penyebab kemiskinan di lokasi ini. Lebih lanjut berdasarkan penelitian tersebut diketahui bahwa jumlah pendapatan per kapita per tahun anggota keluarga petani setara beras $181,23 \mathrm{~kg}$ yang senilai 131,83 US \$ sedangkan standar pendapatan per kapita agar tergolong sejahtera minimal setara beras $\quad 480 \quad \mathrm{~kg} / \mathrm{kapita} /$ tahun (Sumodiningrat, 1999).

Kemiskinan dan rendahnya produktivitas usahatani lahan kering di Desa Tanak Awu adalah dua kondisi yang menjadi penyebab sekaligus akibat dan saling menguat-kan sehingga semakin memiskinkan masyarakat petani lahan kering. Kemiskinan membatasi modal petani untuk menggunakan input pertanian terutama pupuk sesuai rekomendasi sehingga produktivitas dan kualitas produksi serta pendapatan menjadi rendah. Selain itu, kemiskinan mengakibatkan petani tidak mampu mengupah tenaga kerja luar keluarga sehingga luas tanam cenderung lebih sempit dari luas lahan yang dimiliki dan semakin menyempit pada musim tanam kedua. Rata-rata luas tanam tersebut adalah 0,57 ha sedangkan kisaran luas lahan petani sekitar $0,73-1,0$ ha. Kondisi ini sangat kontradiktif dengan potensi kerja kelompok perempuan dalam keluarga petani yang terabaikan keberadaannya secara kultural. Perempuan dalam masyarakat petani ini secara sistematis memiliki akses yang lebih terbatas ke berbagai sumberdaya dibandingkan laki-laki. Dengan terakumulasinya sebagian sumberdaya manusia di rumah akan menghilangkan sebagian potensi penghasilan keluarga sehingga hanya sebagian dari potensi pendapatan yang dapat dicapai sehingga tergolong miskin.

Jumlah penggunaan tenaga kerja menentukan besarnya nilai ekonomi dari tenaga kerja tersebut. Pada tingkat upah yang relatif sama, nilai ekonomi tenaga kerja kelompok perempuan di Desa Tanak Awu lebih rendah dibandingkan tenaga kerja laki-laki. Hal ini akibat dari lebih rendahnya partisipasi kerja kelompok perempuan.

Berbagai upaya aktualisasi potensi produktif perempuan dalam rangka meningkatkan pendapatan diri dan keluarga petani yang diintroduksikan pemerintah mengalami hambatan bahkan sebagian gagal diimplementasikan. Tradisi patriarkhi dalam masyarakat membatasi kemampuan perempuan mengakses sumber daya dan aset-aset produktif. Menurut laporan Bank Dunia (tahun 2005) diketahui bahwa sebagian besar hak atas tanah dan aset produktif serta keputusankeputusan strategis di negara berkembang termasuk Indonesia diberikan kepada laki- 
laki. Secara turun-temurun kondisi ini menimbulkan sikap pesimistis internal kelompok perempuan terhadap potensi diri serta merasa aman dan nyaman dalam tradisi tersebut meskipun memperburuk kualitas kesejahteraan keluarga (Anonim, 2005). Agar segera terbebas dari kemiskinan maka perlu pemberdayaan semua potensi keluarga termasuk potensi kelompok perempuan dengan program selaras tradisi karena merubah tradisi memerlukan waktu relatif lama. Di sisi lain, tuntutan kebutuhan manusia untuk hidup sehat dan layak terus meningkat sehingga perlu upaya peningkatan pendapatan dalam waktu singkat.

Berbagai kebijakan untuk meningkatkan produktivitas pertanian lahan kering dalam pelaksanaannya justeru semakin menguatkan tradisi ini. Terutama jika proses introduksinya dan pengelolaan tidak melibatkan kelompok perempuan serta mengabaikan potensi positi yang ada dalam tradisi patriarkhi. Hasil penelitian Ayu dkk (2014) di Desa Tanak Awu berhasil memformulasikan potensi kerja kelompok perempuan keluarga petani lahan kering. Peluang untuk meningkatkan taraf hidup keluarga melalui pemberdayaan kelompok perempuan di wilayah tersebut masih dimungkinkan karena baru 8,29 \% yang digunakan dari total potensi kerja yang berjumlah 672,95 HKO/tahun.

Hasil penelitian berhasil mengidentifikasi potensi sumberdaya alam /lingkungan yang mendukung pengembangan program yakni lahan pekarangan per keluarga petani sekitar 1 sampai 3 are dan tanpa vegetasi, bahanbahan/sisa panen untuk pembuatan pupuk organik dan tradisi yang mengakibatkan tersedianya waktu luang kelompok perempuan di rumah setelah pekerjaan kerumahtanggaan. Selain itu, potensi pendukung adalah lokasi pemasaran di pasar tradisonal terdekat (Pasar Penujak) dan rumah makan/ restoran di kawasan BIL. Pengembangan sistem pertanian organik di lahan pekarangan menggunakan wadah polybag bertujuan untuk mengefisienkan penggunaan lahan, pupuk organik dan air untuk menyiram tanaman sehingga diperoleh hasil yang terbaik.

Tujuan kegiatan pengabdian ini adalah untuk membangun rasa percaya diri terhadap potensi kerja dan motivasi berusaha kelompok perempuan serta penyadaran terhadap potensi produktif tradisi patriarkhi dalam masyarakat serta meningkatkan kemampuan pemanfaatan potensi lahan pekarangan untuk pengembangan sistem pertanian organik tanaman hortikultura dalam wadah polybag serta potensi pasar di warung/restoran di kawasan BIL. Selain itu diberikan latihan manajemen pengelolaan modal agar usahatani di lahan pekarangannya optimal dan berkelanjutan. Model binaan ini selaras tradisi karena aktivitasnya terpusat di sekitar rumah dan halamannnya.

\section{METODE KEGIATAN}

Kegiatan pengabdian kepada masyarakat ini merupakan implementasi model hasil penelitian Fundamental sumberdana Kemenristek Dikti tahun 2013 dengan judul: "Model Penanggulangan Kemiskinan Berbasis Aktualisasi Potensi Produktif Ibu Rumahtangga dan Anak Perempuannya di P. Lombok (Kasus: Masyarakat Petani Lahan Kering); dengan Tim Peneliti: Candra Ayu, Wuryantoro dan Sri Supartiningsih. Tahap analisis situasi yang mendasar terkait kebutuhan dan 
permasalahan yang dihadapi masyarakat sudah dilakukan dalam proses penelitian untuk merancang model pemberdayaan yang diimplentasikan oleh kegiatan pengabdian ini. Namun, analisis situasi untuk mengecek kondisi saat ini dilakukan di tahap-tahap awal kegiatan.

Tahap-tahap untuk implementasi model binaan dalam upaya pemberdayaan kelompok perempuan yang selaras tradisi masyarakat petani lahan kering di Desa Tanak Awu-Kecamatan Pujut-Lombok Tengah adalah sebagai berikut:

1. Tahap persiapan implementasi model meliputi pengurusan ijin pengabdian, penyusunan buku Pedoman Praktis pengembangan sistem pertanian organik berbasis usahatani hortikultura dalam wadah polybag di halaman pekarangan Desa Tanak Awu - Kecamatan Pujut - Kabupaten Lombok Tengah.

2. Tahap pengadaan bahan-bahan kegiatan pengabdian pada masyarakat

3. Tahap pelatihan, praktek, dan pembinaan langsung oleh tim pelaksana kegiatan dengan metode pendekatan tindak-partisipatif (Participatory Action). Pendekatan tindak-partisipatif (Participatory Action) yaitu suatu bentuk pendekatan yang melibatkan kelompok sasaran pada semua tahapan yang berlangsung selama implementasi kegiatan PPM (Daniel dkk, 2005).

Kegiatan pengabdian ini dilakukan di

Desa Tanak Awu Kecamatan Pujut, Kabupaten Lombok Tengah. Berdasarkan pertimbangan lokasi tersebut merupakan kawasan dengan luas lahan kering terluas di Kabupaten Lombok Tengah dan menjadi salah satu lokasi penelitian skim
Fundamental tahun 2014 tentang model aktualisasi potensi perempuan keluarga petani lahan kering dalam tradisi patriarkhi di Pulau Lombok.

\section{HASIL DAN PEMBAHASAN}

\section{Deskripsi Masyarakat Khalayak Sasaran}

Desa Tanak Awu adalah salah satu desa di Kecamatan Pujut Kabupaten Lombok Tengah, merupakan desa tempat Bandara Internasional Lombok. Wilayah Desa Tanak Awu merupakan pertanian lahan kering yang rata-rata frekuensi tanamnya satu kali per tahun.

Kegiatan pengabdian kepada masyarakat ini dilakukan di Desa Tanak Awu pada bulan September 2018 yang merupakan musim kemarau (Gambar 1).

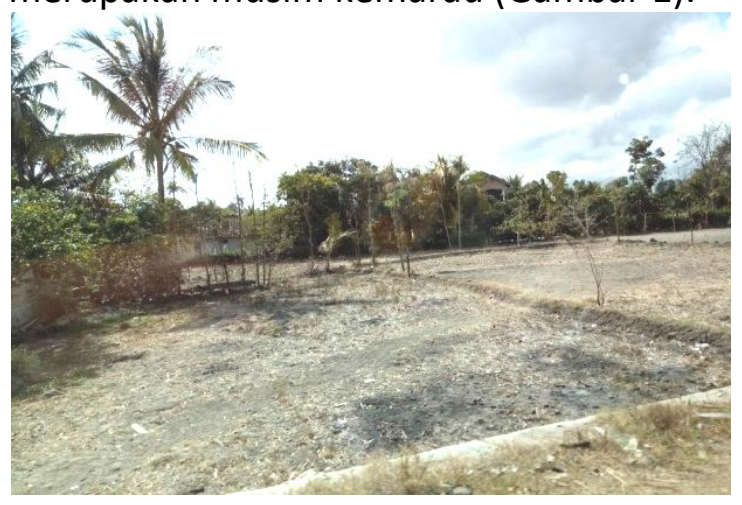

Gambar 1. Lokasi kegiatan

Aktivitas di lahan pertanian di lokasi ini tidak optimal dan umumnya lahan tidak ditanami karena merupakan lahan tadah hujan. Namun hasil pengamatan saat kegiatan PPM terdapat sebagian kecil lahan tersebut milik petani yang bermodal tetap ditanami tembakau virginia yang irigasinya dari air permukaan (air sumur) dengan menggunakan mesin air berbahan bakar solar. Untuk memperoleh penghasilan maka kelompok laki-laki di desa ini sebagian besar menjadi pemulung dan khusus tahun 
2018 pekerjaan ini meningkat pesat akibat bencana gempa yang banyak merobohkan rumah/bangunan di Kabupaten Lombok Utara. Secara rutin besi-besi rangka bangunan yang roboh/rusak di KLU diangkut ke Desa Tanak Awu untuk dibersihkan dari betonnya untuk selanjutnya dijual ke Surabaya menggunakan truk-truk Fuso. Dalam situasi ini kelompok perempuan tidak bertani sehingga mempunyai banyak waktu luang setelah kegiatan rutin terkait dengan perannya sebagai ibu rumah tangga. Berdasarkan hasil analisis situasi tersebut maka sangat tepat dilakukan kegiatan pengabdian kepada masyarakat ini.

Kegiatan pengabdian kepada
masyarakat ini dilakukan untuk
pemberdayaan ekonomi kelompok perempuan melalui budidaya hortikultura secara organik dalam polybag di lahan pekarangan di Desa Tanak Awu Kecamatan Pujut Kabupaten Lombok Tengah. Penyuluhan tentang model binaan ini diperlukan masyarakat untuk menambah penghasilan keluarga karena pekerjaan sebagai pemulung bersifat jangka pendek dan upahnya kurang dari Rp 50 000/orang/hari. Selain itu, potensi halaman pekarangan per rumah tangga cukup luas sekitar 2-4 are sehingga dapat sebagai lahan bertanam tanaman pangan semusim dalam sistim polybag.

\section{Tahapan Pelaksanaan}

1. Tahap persiapan untuk pelaksanaan kegiatan pengabdian/penyuluhan dilakukan tanggal 16 sampai 20 September 2018, meliputi kegiatan:

a. Pembentukan kelompok binaan yang terdiri dari ibu rumahtangga dan anak perempuan yang bersedia dibina dan dibuktikan dengan kehadiran selama kegiatan berlangsung.

b. Penetapan lokasi kegiatan dan pengurusan ijin kegiatan pengabdian ke aparat pemerintahan Desa Tanak Awu-Kampung Gantang.

c. Penyusunan materi penyuluhan untuk budidaya tanaman sayuran di lahan pekarangan dalam media polybag.

d. Inventarisasi ketersediaan alat dan bahan lokal (tanah, pupuk kandang/kompos, bambu, wadahwadah plastik air minum kemasan yang dapat difungsikan serupa polybag) untuk digunakan untuk pembuatan rak tanaman dan untuk membuatan media tanam.

2. Tahap pengadaan alat dan bahanbahan kegiatan pengabdian pada masyarakat, yakni persiapan alat-alat untuk pembuatan rak tanaman menggunakan bahan-bahan yang tersedia di lokasi (bambu), pengumpulan bahan-bahan lokal untuk menjadi media tanam (tanah, kotoran ternak yang sudah jadi kompos) dan pengumpulannya, serta pengadaan benih/bibit tanaman sayuran. Kegiatan ini dilakukan bersama kelompok sasaran yang telah dibentuk sebelumnya.

3. Tahap pelaksanaan kegiatan pengabdian/penyuluhan untuk pemberdayaan kelompok perempuan melalui budidaya hortikultura secara organik dalam polybag di lahan pekarangan Desa Tanak Awu Kecamatan Pujut - Kabupaten Lombok Tengah. Pelaksanaan kegiatan ini tanggal 22 dan 23 September 2018, merupakan rangkaian aktivitas pelatihan dan penyuluhan, praktek, dan pembinaan/pendampingan langsung 
oleh tim pelaksana kegiatan dengan metode pendekatan tindak-partisipatif (Participatory Action) yang melibatkan kelompok sasaran pada semua tahapan kegiatan pengabdian (gambar 2). Rangkaian aktivitas pada penyuluhan ini adalah:

a. Memberi penyuluhan untuk membangun rasa percaya diri terhadap potensi kerja dan motivasi berusaha kelompok perempuan yang relevan tradisi di Desa Tanak Awu-Kecamatan Pujut -Lombok Tengah (tradisi di masyarakat binaan bahwa kelompok perempuan tidak diijinkan bekerja di luar rumah dan disini sama sekali tidak ada yang menjadi TKI/TKW).

b. Memberi penyuluhan tentang potensi produktif tradisi patriarkhi yang dianut masyarakat serta potensi lahan pekarangan untuk pengembangan sistem pertanian organik tanaman hortikultura.

c. Memberi penyuluhan tentang berbagai jenis pupuk organik dan demontrasi pembuatannya serta teknik pengembangan usahatani hortikultura secara organik dengan wadah polybag di halaman pekarangan. Termasuk dalam sub kegiatan ini adalah membuat rak untuk tanaman sehingga per luas lahan pekarangan yang ada dapat ditanam banyak jumlah dan jenis tanaman. Selian itu, penempatan tanaman di rak akan melindungi dari gangguan ayam yang umumya dipelihara secara tradisional dengan dilepas di sekitar rumah pemilik.

d. Memberi penyuluhan tentang potensi pasar di Kawasan Bandara
Internasional Lombok dan pasar tradisonal yang berlokasi di desa sebelahnya (Desa Penujak) untuk produksi hortikultura yang disuluhkan.

e. Memberi penyuluhan disertai praktek tentang manfaat ekonomi kegiatan pengabdian masyarakat dan dampaknya terhadap peningkatan pendapatan dan taraf hidup keluarga petani di Desa Tanaq Awu-Kecamatan Pujut Lombok Tengah.

f. Memberi penyuluhan dan sekaligus praktik pembukuan keuangan sederhana untuk menilai keberhasilan pengelolaan program yang disuluhkan sehingga terwujud sumber nafkah berkelanjutan sepanjang tahun.

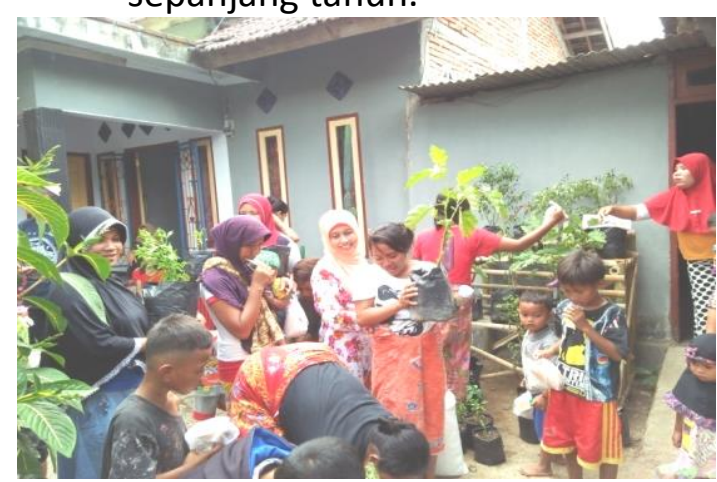

Gambar 2. Keterlibatan mitra

4. Tahap evaluasi hasil pelaksanaan pengabdian kepada masyarakat terutama dari aspek kinerja ekonominya yang mampu memberi pendapatan masyarakat binaan dan menumbuhkan sumber pendapatan yang baru sekaligus memberi nilai ekonomi bagi kelompok perempuan di Desa Tanak Awu. 


\section{KESIMPULAN DAN SARAN}

\section{Kesimpulan}

Terbukanya wawasan berfikir dan meningkatnya rasa percaya diri terhadap potensi kerja dan motivasi berusaha kelompok perempuan yang relevan tradisi di Desa Tanak Awu-Kecamatan Pujut Lombok Tengah

Membangun kesadaran berusaha dan motivasi kuat untuk memanfaatkan potensi produktif ekonomi yang dimiliki sehingga menghasilkan pendapatan tanpa mengabaikan fungsi utamanya terkait peran sebagai ibu rumahtangga. Produksi hasil budidaya berbagai hortikultura di lahan pekarangan dapat untuk konsumsi rumahtangga dan jika dilakukan secara rutin dalam skala yang lebih banyak maka akan menghasilkan pendapatan meskipun di musim kemarau.

Bertambahnya

pengetahuan kelompok perempuan tentang berbagai jenis pupuk organik dan demontrasi pembuatannya serta teknik pengembangan usahatani hortikultura secara organik dengan wadah polybag di halaman pekarangan, serta bertambahnya pengetahuan tentang cara membuat rak untuk tanaman dari bahan-bahan yang tersedia di lokasi sehingga per luas lahan pekarangan yang ada dapat ditanam banyak jumlah dan jenis tanaman.

\section{Saran}

Berdasarkan pelaksanaan kegiatan
di lapangan maka diharapkan perlunya
kegiatan pengabdian lanjutan di Desa
Tanak Awu Kecamatan Pujut Lombok
Tengah untuk mendampingi kelompok
perempuan binaan agar terjadi
keberlanjutan pengembangan kegiatan
produktif inovatif yang disuluhkan serta

membuka jaringan pemasaran yang menguntungkan.

\section{DAFTAR PUSTAKA}

Anonim, 2005. Pembangunan Berperspektif Gender melalui Kesetaraan Gender dalam Hak, Sumberdaya dan Aspirasi. Laporan Penelitian Kebijakan Bank Dunia. Dian Rakyat. Jakarta.

Candra Ayu, Wuryantoro dan Sri Supartiningsih. 2014. Model Penanggulangan Kemiskinan Berbasis Aktualisasi Potensi Produktif Ibu Rumahtangga dan Anak Perempuannya di P. Lombok (Kasus: Masyarakat Petani Lahan Kering). Makalah pada Seminar Nasional Pengelolaan Lahan Terdegradasi untuk Menjamin Keamanan dan Ketahanan Pangan. Unram-Mataram.

Daniel, M., Darmawati dan Nieldalina. 2005. PRA: Participatory Rural Appraisal: Pendekatan Efektif Mendukung Penerapan Penyuluhan Partisipatif dalam Upaya Percepatan Pembangunan Pertanian. Penerbit PT Bumi Aksara. Jakarta.

Sumodiningrat, G. Santosa, B. dan Maiwan, M. 1999. Kemiskinan: Teori, Fakta dan Kebijakan. Edisi Pertama, Penerbit IMPAC. Jakarta. 